\title{
Can We Predict Mortality in Patients with Fournier's Gangrene Using Questionnaires? A Pilot Study with Eighty-seven Patients
}

\author{
Fournier Gangrenine Bağlı Ölümleri Anketlerle Öngörebilir miyiz? Seksen Yedi Hastayla \\ Yapılan Pilot Bir Çalışma
}

\author{
(D) Soner Yalçınkaya, (D) Ali Yıldız, (D) Mustafa Yüksel, (D) Ekrem İslamoğlu, (D) Nihat Ateş, (D) Hüsnü Tokgöz, (D) Murat Savaş \\ University of Health Sciences, Antalya Training and Research Hospital, Clinic of Urology, Antalya, Turkiye
}

\section{What's known on the subject? and What does the study add?}

The mortality of Fournier's gangrene still distresses doctors and scoring systems are developed to predict the outcomes of patients. This study confirms the effectiveness of these scoring systems and recommends to use these tools to decide which patients should be treated more aggressively.

\begin{abstract}
Objective: To investigate the validity and reliability of the Fournier's gangrene severity index (FSGI) and Uludag Fournier's gangrene severity index (UFGSI) scoring systems and their components in outcome prediction for patients with Fournier's gangrene.

Materials and Methods: Recods of 87 patients, who were diagnosed with Fournier's gangrene in our clinic between March 2005 and May 2016 , were retrospectively analyzed. The patients were divided into 2 groups as survivors and non-survivors. Parameters belonging to the groups were compared.

Results: The overall mortality rate was $13.7 \%$. There was no correlation between mortality and dissemination of disease to the rectum, lower abdomen or lower extremity ( $p>0.05)$. There was a significant difference in renal failure, heart rate, blood urea nitrogen, creatinine, calcium and serum bicarbonate $\left(\mathrm{HCO}_{3}\right)$ values, and FSGI and UFGSI scores between the survivor and non-survivor groups ( $\left.<<0.05\right)$. In evaluation of mortality, a cut-off value of $\geq 9$ had a positive predictive value of $77.8 \%$ and $42.9 \%$ and negative predictive value of $93.6 \%$ and $95.5 \%$ for FGSI and UFGSI, respectively.

Conclusion: To predict the prognosis in Fournier's gangrene, the FGSI and UFGSI are successful parameters especially in predicting mortality. In the light of these parameters, we assume that these scoring systems are useful in deciding which patient should receive more aggressive treatment. Keywords: FGSI, Fournier's gangrene, Mortality, UFGSI
\end{abstract}

\section{Öz}

Amaç: Fournier's gangrene severity index (FGSi) ve Uludag Fournier's gangrene severity index (UFGSi) skorlama sistemlerinin ve komponentlerinin Fournier gangrenini değerlendirmedeki geçerliliklerini ve güvenilirliklerini değerlendirmek.

Gereç ve Yöntem: Mart 2005 ve Mayıs 2016 tarihleri arasında, kliniğimizde Fournier gangreni tanısı alan 87 hastanın kayıtları retrospektif olarak incelendi. Hastalar hayatta kalanlar ve kalmayanlar olarak iki gruba ayrıldı. Her iki gruba ait parametreler birbiriyle karşılaştırıldı.

Bulgular: Tüm hastalardaki mortalite oranı \%13,7 idi. Mortalite ile hastalığın rektuma, alt abdomene veya alt ekstremiteye yayılması arasında anlamlı bir bağlantı bulunamadı ( $>>0,05)$. Hayatta kalanlar ve kalmayanlar grupları arasında; böbrek yetmezliği, kalp atım hızı, kan üre nitrojeni, kreatinin, kalsiyum ve serum bikarbonat $\left(\mathrm{HCO}_{3}\right)$ değerleriyle birlikte FGSi ve UFGSi skorlarında anlamlı bir farklılık vardı $(p<0,05)$. Eşik değer 9 olarak kabul edildiğinde; FGSi'nin mortalite için pozitif ve negatif prediktivitesi sırasıyla \%77,8 ve \%93,6; UFGSi'nin ise sırasıyla \%42,9 ve \%95,5 olarak hesaplandı.

Sonuç: FGSi ve UFGSI, Fournier gangreni hastalarının prognozunu öngörmek, özellikle de hastalığın mortalitesinin negatif prediktivitesini hesaplamak için çok başarılı skorlama sistemleridir. Bu bilgiler ışığında, bazı hastalara ilk aşamada daha agresif tedaviler başlamak akıllıca bir yaklaşım olacaktır. Anahtar Kelimeler: FGSi, Fournier's gangreni, Mortalite, UFGSi

Correspondence: Ekrem İslamoğlu MD, University of Health Sciences, Antalya Training and Research Hospital, Clinic of Urology, Antalya, Turkiye Phone: +90 2422494400 E-mail: meislamoglu@gmail.com ORCID-ID: orcid.org/0000-0003-0693-0666

Received: 1.10 .2018

Accepted: 5.12 .2018

Cite this article as: Yalçınkaya S, Yıldız A, Yüksel M, İslamoğlu E, Ateş N, Tokgöz H, Savaş M. Can We Predict Mortality in Patients with Fournier's Gangrene Using Questionnaires? A Pilot Study with Eighty-seven Patients. J Urol Surg 2019;6(2):118-124.

๑Copyright 2019 by the Association of Urological Surgery / Journal of Urological Surgery published by Galenos Publishing House. 


\section{Introduction}

Fournier's gangrene (FG) is polymicrobial, necrotizing fasciitis of the genital organs, perineal and perianal regions. It is characterized by thrombotic occlusion of the subcutaneous arteries resulting in gangrene of the subcutaneous tissue and the overlying skin (1). Diabetes mellitus (DM) and immunosuppression are common predisposing factors for vascular disease and suppressed immunity. Other predisposing factors described in the literature are obesity, peripheral vascular disease, local trauma, urethral stricture and perianal disease $(2,3,4)$. Although radiological evaluation can show the extent of the disease, the diagnosis is mainly based on physical examination. Broad-spectrum antibiotic therapy with aggressive surgical debridement is the standard treatment for $F G$, however, mortality rates are high even among well-managed patients.

In 1995, Laor et al. (5) published the FG severity index (FGSI) to predict outcome of patients. Later, YIImazlar et al. (6) introduced the Uludag Fournier's gangrene severity index (UFGSI) which is a larger scoring system adding age and disease extension to FGSI. These scoring systems have been widely used in published FG literature. In this study, we investigated reliability and validity of the FGSI and UFGSI scoring systems and their components in outcome prediction for patients with Fournier's gangrene.

\section{Materials and Methods}

Medical records of 87 patients, who were diagnosed with FG in our clinic between March 2005 and May 2016, were retrospectively analyzed. The diagnosis of FG was based on history and physical examination. Patients without soft tissue extension or necrosis and patients with a solitary periurethral, scrotal or perianal abscess were excluded from the study. Pediatric patients were also excluded. All patients were treated with empiric broad-spectrum parenteral antibiotics until a specific therapy based on a resistogram was available. Culture samples were taken from wounds/tissues and processed in the microbiology laboratory. Anaerobic cultures could not be applied due to technical difficulties. Fluid resuscitation was applied preoperatively and intraoperatively.

All patients underwent urgent aggressive debridement, with resection of all necrotic tissue until the viable tissue was reached. Conventional wound dressings were changed daily and if necessary, debridement was repeated every 24-48 hours. While wide debridement was performed under regional or general anesthesia, more limited debridement was performed under sedation. Nutritional support was provided for patients who were suffering from malnutrition. Patients who required vasopressors or mechanical ventilation were treated in the intensive care unit. Suprapubic cystostomy was performed if there was periurethral involvement causing urinary extravasation. Colostomy was performed by a general surgery team when anal sphincter involvement was present. Other treatment methods, such as vacuum-assisted closure (VAC; Kinetic Concepts, Inc., San Antonio, TX) and hyperbaric oxygen therapy, were not used. Small wound areas were left for secondary healing or delayed primary closure. Local skin flaps or tissue grafts were used in patients with large soft-tissue defects.

Patient demographics, co-morbidities, source of infection, FGSI score, UFGSI score, extent and number of surgical interventions, microbiological analysis results, and length of hospital stay were recorded. Mortality was defined as disease-related death during hospitalization. Patients were divided into two groups as survivors and non-survivors. Parameters belonging to the groups were compared. FGSI is a scoring system that can predict mortality in patients with Fournier's gangrene. Laor et al. (5) modified the APACHE II scoring system to create the FGSI and used this scoring system widely in their own clinical practice. Yilmazlar et al. (6) added patient age and disease disseminatiton to FGSI to produce UFGSI (Table 1). Both FGSI and UFGSI are short scoring systems which are easy to use and both of them are claimed to be effective in predicting mortality in patients with FG.

Written informed consent was obtained from each patient and our study was conducted in accordance with the principles of the Helsinki Declaration. Patients' data were retrospectively analyzed to evaluate the clinical outcomes. Ethics committee approval was not obtained due to the retrospective design of the study.

\section{Statistical Analysis}

For descriptive statistics of the data, mean, standard deviation, median, minimum, maximum, frequency and percentage values were used. Distribution of the variables was analyzed with the Kolmogorov-Smirnov Test. Quantitative data analysis was performed with the Mann-Whitney $U$ test and independent samples t-test. Qualitative data analysis was performed with the chi-square test; if chi-square test was not suitable the Fischer's exact test was used. The effect levels and cut off values were researched with the receiver operating characteristic (ROC) curve. Analyses were completed with the IBM SPSS Statistics for Windows, version 22.0 (IBM Corp., Armonk, NY).

\section{Results}

The study included 87 patients. Twelve patients died, leading to a mortality rate of $13.7 \%$. The mean age of 87 patients was $59.4 \pm 14.5$ years. The median age of the survivors was $58.0 \pm 13.5$ and the median age of non-survivors was $68.5 \pm 17.9$ years. The difference was not statistically significant. $(p=0.072)$. There was 
no correlation between mortality and sex $(p>0.05)$. The mean time between onset of symptoms and hospital admission was 8 days (range 2-23). The mortality rate in patients who were taken to hospital 8 days after the onset of symptoms was $16.6 \%$. Fortyone patients (47.1\%) had an anorectal pathology as the source of infection, 34 patients had urogenital pathologies (39\%) and 12 patients (13.7\%) had skin infections as an etiological factor. Thirty-one patients (35.6\%) had anemia requiring preoperative transfusion.

The first debridement was generally performed under regional anesthesia, while 16 patients (18.3\%) needed general anesthesia. During the operations, colostomy was performed in six patients $(6.89 \%)$ and percutaneous cystostomy was performed in four patients (4.59\%). Fifty patients (57.4\%) had positive cultures from wounds or tissues.

The most common isolated microorganisms were examined and 16 patients had Escherichia coli, 7 had Enterococcus feacalis, 6 had Pseudomonas aeruginosa, 5 had Acinetobacter species and 5 patients had Staphylococci species. Positive culture rate in the survivor group (61.3\%) was higher compared to the nonsurvivor group (33.3\%), but the difference was not statistically significant $(p=0.069)$.

The correlation between mortality and the dissemination to

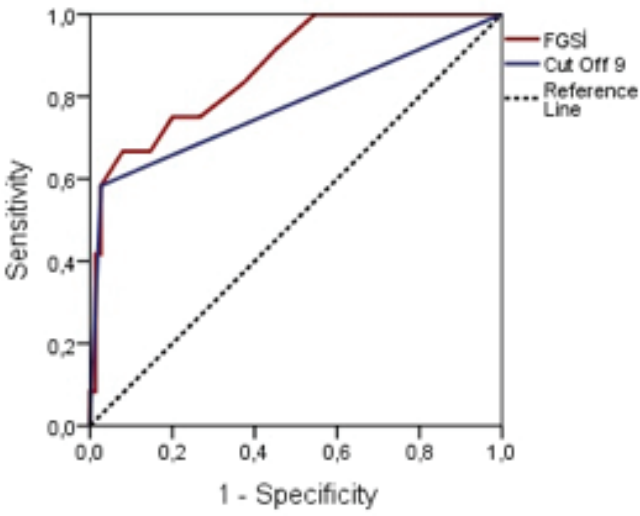

Figure 1. Receiver operating characteristic curves of the Fournier's gangrene severity index and Uludag Fournier's gangrene

FGSi: Fournier's gangrene severity index

Table 2. Correlation between dissemination of infection and the mortality

\begin{tabular}{llllllll}
\hline & \multicolumn{2}{l}{$\begin{array}{l}\text { Non- } \\
\text { survivor }\end{array}$} & \multicolumn{2}{l}{ Survivor } & \multicolumn{2}{l}{$\mathbf{p}$} & \\
\cline { 2 - 6 } & $\mathbf{n}$ & $\%$ & $\mathbf{n}$ & $\%$ & & \\
\hline Extention to rectum & 4 & $33.3 \%$ & 16 & $21.3 \%$ & 0.359 & $\mathrm{x}^{2}$ \\
\hline Extension to lower abdomen & 1 & $8.3 \%$ & 8 & $10.7 \%$ & 1.000 & $\mathrm{x}^{2}$ \\
\hline Extension to lower extremity & 2 & $16.7 \%$ & 6 & $8.0 \%$ & 0.304 & $\mathrm{x}^{2}$ \\
\hline X2 Chi-square test (Fischer test) & & & & & &
\end{tabular}

Table 1. Fournier's gangrene severity index (5) and Uludag Fournier's gangrene severity index A (6) (a: Fournier's gangrene severity index, $a+b+c$ : Uludag Fournier's gangrene severity index)

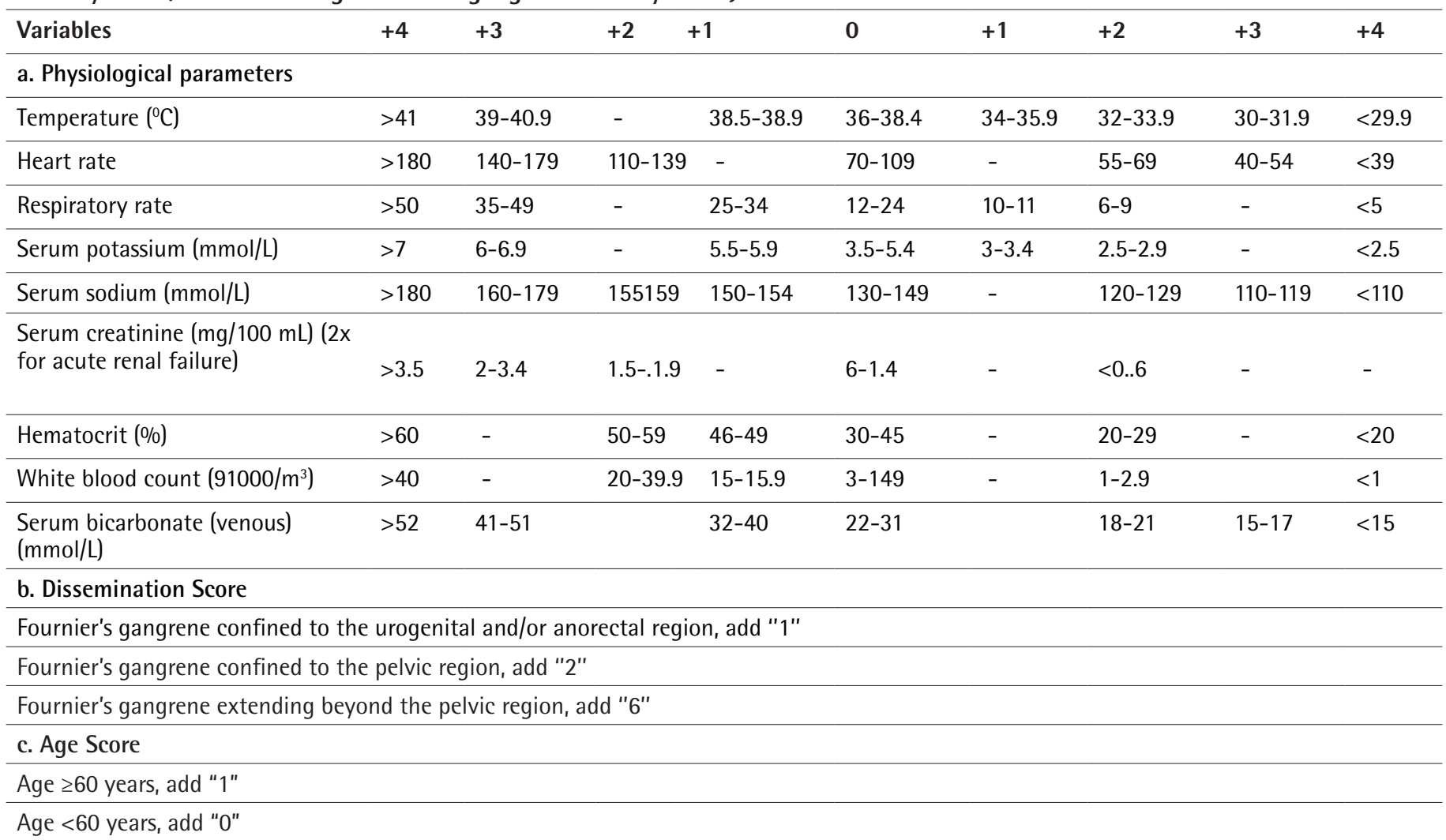


the rectum, lower abdomen or lower extremity is investigated in Table 2. There was no correlation between mortality and dissemination of infection in the survivor and non-survivor groups ( $p>0.05$ ). The demographic data, comorbidities, laboratory parameters, FGSI and UFGSI scores of survivor and non-survivor groups were compared in Table 3. Of these parameters, there was a significant difference between the groups for renal failure; heart rate; serum blood urea nitrogen (BUN), creatinine, $\mathrm{Ca}$, and $\mathrm{HCO}_{3}$ values, as well as FSGI and UFGSI scores $(p<0.05)$. The efficacy of FGSI and UFGSI scores were investigated with a ROC curve (Figure 1). When a cut-off value 9 was accepted for both scores; the sensitivity, specificity, positive and negative predictive values were calculated and shown in Table 4.

Table 3. Comparison of survivors with non-survivors in terms of demographic data, comorbidities, labouratuary parameters, Fournier's gangrene severity index and Uludag Fournier's gangrene severity index scores

\begin{tabular}{|c|c|c|c|c|c|c|c|c|c|c|c|c|c|c|c|c|c|}
\hline \multirow{3}{*}{\multicolumn{2}{|c|}{ Mean \pm SD/n- $\%$}} & \multicolumn{6}{|c|}{ Non-survivor } & \multicolumn{6}{|c|}{ Survivor } & & & \multicolumn{2}{|l|}{ p } \\
\hline & & \multirow[b]{2}{*}{68.5} & \multirow[b]{2}{*}{ \pm} & \multicolumn{4}{|c|}{ Med (min-max) } & \multicolumn{3}{|c|}{ Mean $\pm \mathrm{SD} / \mathrm{n}-\%$} & \multicolumn{5}{|c|}{ Med (min-max) } & \multirow[b]{2}{*}{0.072} & \multirow[b]{2}{*}{$\mathrm{t}$} \\
\hline & & & & 17.9 & 63 & 40 & - & 95 & 58.0 & \pm & 13.5 & 59 & 25 & - & 88 & & \\
\hline \multirow[t]{2}{*}{ Gender } & Female & 2 & - & $16.7 \%$ & - & - & - & - & 12 & - & $16.0 \%$ & - & - & - & - & \multirow[t]{2}{*}{1.00} & \multirow[t]{2}{*}{$x^{2}$} \\
\hline & Male & 10 & - & $83.3 \%$ & - & - & - & - & 63 & - & $84.0 \%$ & - & - & - & - & & \\
\hline DM (+) & & 8 & - & $66.7 \%$ & - & - & - & - & 38 & - & $50.7 \%$ & - & - & - & - & 0.303 & $\mathrm{~m}$ \\
\hline $\mathrm{RF}(+)$ & & 5 & - & $41.7 \%$ & - & - & - & - & 3 & - & $4.0 \%$ & - & - & - & - & 0.001 & $\mathrm{~m}$ \\
\hline \multicolumn{2}{|c|}{ Wound culture+ } & 4 & - & $33.3 \%$ & - & - & - & - & 46 & - & $61.3 \%$ & - & - & - & - & 0.069 & $\mathrm{~m}$ \\
\hline \multicolumn{2}{|c|}{ Temperature $\left({ }^{\circ} \mathrm{C}\right)$} & 38.0 & \pm & 1.4 & 39 & 35 & - & 40 & 37.8 & \pm & 1.0 & 38 & 36 & - & 40 & 0.202 & $\mathrm{~m}$ \\
\hline \multicolumn{2}{|l|}{ HTC (\%) } & 33.0 & \pm & 6.4 & 32 & 26 & - & 46 & 33.0 & \pm & 6.1 & 32 & 19 & - & 50 & 0.883 & $\mathrm{~m}$ \\
\hline \multicolumn{2}{|c|}{ WBC (total $\left./ \mathrm{mm}^{3} \times 1000\right)$} & 19.5 & \pm & 12.6 & 14 & 4 & - & 45 & 15.3 & \pm & 8.3 & 14 & 1 & - & 34 & 0.424 & $\mathrm{~m}$ \\
\hline \multicolumn{2}{|c|}{ BUN (mg/dL) } & 63.7 & \pm & 44.8 & 53 & 21 & - & 176 & 25.6 & \pm & 17.2 & 20 & 6 & - & 102 & 0.000 & $\mathrm{~m}$ \\
\hline \multicolumn{2}{|c|}{ Creatinine (mg/dL) } & 2.6 & \pm & 1.6 & 2.5 & 0,6 & - & 5.3 & 1.3 & \pm & 1.1 & 0.9 & 0,5 & - & 8.7 & 0001 & $\mathrm{~m}$ \\
\hline \multicolumn{2}{|c|}{$\mathrm{Na}(\mathrm{mmol} / \mathrm{L})$} & 133.8 & \pm & 6.5 & 134 & 121 & - & 142 & 134.7 & \pm & 4.8 & 135 & 119 & - & 145 & 0.721 & $\mathrm{~m}$ \\
\hline \multicolumn{2}{|c|}{ K (mmol/L) } & 4.7 & \pm & 1.4 & 4 & 3 & - & 7 & 4.1 & \pm & 0.8 & 4 & 1 & - & 6 & 0.280 & $\mathrm{~m}$ \\
\hline $\mathrm{Cl}(\mathrm{mmo}$ & & 101.9 & \pm & 4.9 & 103 & 94 & - & 108 & 101.2 & \pm & 5.3 & 102 & 85 & - & 111 & 0.688 & $\mathrm{~m}$ \\
\hline $\operatorname{ALT}(\mathrm{U} / \mathrm{L})$ & & 21.9 & \pm & 17.9 & 18 & 5 & - & 56 & 24.1 & \pm & 18.3 & 17 & 4 & - & 86 & 0.402 & $\mathrm{~m}$ \\
\hline AST (U/L & & 40.1 & \pm & 32.2 & 30 & 10 & - & 124 & 26.1 & \pm & 14.1 & 22 & 8 & - & 81 & 0.101 & $\mathrm{~m}$ \\
\hline Number & f debridments & 1.3 & \pm & 0.7 & 1.0 & 1.0 & - & 3.0 & 2.0 & \pm & 1.5 & 1.0 & 1.0 & - & 8.0 & 0.123 & $\mathrm{~m}$ \\
\hline FGSI & & 10.0 & \pm & 4,8 & 10 & 3 & - & 20 & 3.7 & \pm & 3.2 & 3 & 0 & - & 15 & 0.000 & $\mathrm{~m}$ \\
\hline UFGSI & & 12.3 & \pm & 5.6 & 12 & 5 & - & 26 & 6.2 & \pm & 3.5 & 6 & 1 & - & 16 & 0.000 & $\mathrm{~m}$ \\
\hline
\end{tabular}

${ }^{m}$ Mann-Whitney U test, ${ }^{t}$ test, ${ }^{{ }^{2}} \mathrm{Chi}$-square test (Fischer test) SD: Standart deviation, min: Minimum, max: Maximum, n: number, DM: Diabetus mellitus; HT: Hypertension, RF: Renal failure, Hb: Hemoglobin, HTC: Hematocrit, WBC: White blood cell, BUN: Blood urea nitrogen, ALT: Alanine aminotransaminase, AST: Aspartate aminotransferase, ROC: Receiver operating characteristic UFGSI: Uludag Fournier's gangrene severity index, FGSI: Fournier's gangrene severity index 
Table 4. Analysis of Fournier's gangrene severity index and Uludag Fournier's gangrene severity index

\begin{tabular}{|c|c|c|c|}
\hline & AUC & $95 \% \mathrm{Cl}$ & $\mathbf{p}$ \\
\hline UFGSI & 0.835 & $0.713-0.957$ & 0.000 \\
\hline \multirow[t]{6}{*}{ Cut off 9} & 0.795 & $0.644-0.946$ & 0.001 \\
\hline & \multicolumn{2}{|c|}{ Sensivity } & $75.0 \%$ \\
\hline & \multicolumn{2}{|c|}{ Positive predictivity } & $42.9 \%$ \\
\hline & \multicolumn{2}{|c|}{ Specificity } & $84.0 \%$ \\
\hline & \multicolumn{2}{|c|}{ Negative predictivity } & $95.5 \%$ \\
\hline & AUC & $95 \% \mathrm{Cl}$ & $\mathrm{p}$ \\
\hline FGSI & 0.869 & $0.764-0.975$ & 0.000 \\
\hline \multirow[t]{5}{*}{ Cut off 9} & 0.778 & $0.601-0.955$ & 0.002 \\
\hline & \multicolumn{2}{|c|}{ Sensivity } & $58.3 \%$ \\
\hline & \multicolumn{2}{|c|}{ Positive predictivity } & $77.8 \%$ \\
\hline & \multicolumn{2}{|c|}{ Specificity } & $97.3 \%$ \\
\hline & \multicolumn{2}{|c|}{ Negative predictivity } & $93.6 \%$ \\
\hline
\end{tabular}

AUC: Area under curve, UFGSI: Uludag Fournier's gangrene severity index, FGSI: Fournier's gangrene severity index

\section{Discussion}

As described initially by Alfred Fournier in 1883, FG is a lifethreatening necrotizing fasciitis (7). FG is a relatively rare disease. Population-based studies have reported that the overall incidence of FG was 1.6/100.000 males between 2001 and 2004 in the United States (8). Though FG mainly affects men, it is also observed in women. A review of 1726 patients reported a male/female ratio of 10:1 (9). In our study, there was 14 female $(16 \%)$ and 73 male $(83.9 \%)$ patients. When studies with a large number of cases were investigated, mean age appears to vary between 54 and 61 years $(10,11,12,13)$. In our study, the median age was 59, which was compatible with the literature. When the literature was reviewed, it was observed that the mortality rate varied between 3\% and 45\% (9). In spite of aggressive surgical debridement, broad-spectrum antibiotic usage, and more developed intensive care support, current publications have reported mortality rates between $14.5 \%$ and $31.5 \%$ $(10,11,12,13,14,15)$. In our study, the mortality rate was $13.7 \%$, showing that $F G$ continues to be a life-threatening disease even today. Among the systemic diseases causing $\mathrm{FG}$, there are $\mathrm{DM}$, HIV infection, leukemia and chronic alcoholism (9). Although the most common systemic disease observed to be associated with FG is DM, some large-scale studies have not found a correlation between the presence of DM and mortality, similar to our results $(11,12,14)$. Additionally, a variety of series have reported a correlation between mortality and comorbidities such as paraplegia and renal failure $(10,11,14)$. In our study, renal failure increased the mortality risk $(p=0.001)$.
In addition to classic approaches, currently hyperbaric oxygen treatment is commonly used for the treatment of FG. As hyperbaric oxygen treatment increases tissue oxygenation, it prevents the development of anaerobic microorganisms and increases neutrophil phagocytic function, fibroblast proliferation and angiogenesis. It also reduces tissue edema through vasoconstriction and increases intracellular antibiotic transport, thus, it is thought that this modality may be effective in the treatment of FG $(16,17)$. Another new treatment method is vacuum-assisted closure (VAC; Kinetic Concepts, Inc., San Antonio, TX) with the promising first results, however, studies with larger number of cases will be determinative $(18,19)$. In addition to these, topical treatments using honey or lyophilized collagenase are still at the experimental stage.

To avoid contamination of necrotic wounds involving the anal region, opening a colostomy is a commonly used method. In our study, colostomy was performed in six patients (6.89\%). To avoid colostomy-related complications, use of a collector tube to empty feces appears to provide promising results, though it is only at the trial stage (20).

Since the mortality rate in patients with FG is high, researchers investigated a variety of parameters to predict the severity and mortality of $F G$, and produced scoring systems or adapted scoring systems developed for some other diseases to FG. The first results published by Laor et al. (5) found that an FGSI score above 9 had a positive predictive value of 75\% for mortality, while scores of 9 or lower were related to a 78\% probability of survival. In a study with 68 patients published in 2008 (11), the FGSI scores of survivor and non-survivor groups were $5.4 \pm 3.5$ and $10.9 \pm 4.7$, respectively $(p=0.006)$. Additionally, the same study found a correlation between mortality and abdominal wall $(p=0.004)$ and lower extremity involvement $(p=0.005)$, however, mean total body surface area was not correlated with mortality ( $p=0.169)$. In our study, we did not find a correlation between mortality and dissemination of disease to the lower abdomen, lower extremity or the rectum $(\mathrm{p}<0.05)$. In a study including 54 patients, the survivor group had the mean FGSI score of 3.8, while this score was 9.4 in the non-survivor group (15). A study by Lin et al. (21) with 84 patients, the mean FGSI score in the survivor group was $5.5 \pm 2.7$, while this score was $10.2 \pm 4.6$ in the non-survivor group ( $p=0.001)$. The same study investigated the subparameters of FGSI and found significant differences in serum creatinine, hematocrit, and potassium values between the two groups. In our study, there was a significant difference in FGSI sub-parameters, such as heart rate, serum $\mathrm{HCO}$, and creatinine between the two groups. In the literature, studies examining FGSI sub-parameters between survivor and nonsurvivor groups have found differences in different variables. However, in many studies, the total FGSI score was found to be higher in non-survivors $(11,13,21,22)$. 
In 2010, YIlmazlar et al. (6) published another scoring system called UFGSI aiming to improve the FGSI. An UFGSI score above 9 showed a 94\% probability of death, while scores of 9 and below were associated with an $81 \%$ probability of survival. A study including 120 patients published by Yilmazlar et al. (6) in 2014 found that an UFGSI score 9 and above was a significant predictor of mortality ( $p=0.001)$ (12). In our study, a cut off value of $\geq 9$ for FGSI was correlated with a $77.8 \%$ probability of mortality, with high sensitivity and specificity rates. However a cut off value of $\geq 9$ for UFGSI had a relatively low positive predictive value (42.9\%). Using a higher cut off value for UFGSI could improve the positive predictive value, but it should be kept in mind that higher cut off values can decrease the sensitivity of UFGSI. When the literature is investigated, there appears to be no consensus for a cut off value. Moreover, FGSI forms the physiological parameters (Table 1) of UFGSI and these have been tested many times to date. However, our results call sufficiency of dissemination score and age score of UFGSI in question. For predicting mortality in patients with $\mathrm{FG}$, scoring systems, such as Charlson comorbidity index and surgical apgar score, have been shown to be as effective as FGSI and UFGSI, but larger series are required to support this data $(14,22)$. In addition, although some publications have found a correlation between mortality and independent laboratory parameters, such as high lactate, hypercalcemia, high blood urea nitrogen, hypomagnesemia, hypalbuminemia and high alkaline phosphatase, there are variations in these parameters between studies $(11,13,22,23)$. In our study, high blood urea nitrogen and hypercalcemia were associated with mortality. In the literature, similar to independent laboratory parameters, studies investigating the correlation between mortality and total body surface area affected by disease revealed contradictory results $(13,14)$. According to our study, blood urea nitrogen and calcium levels can be added to FGSI and UFGSI, but larger studies are required to support this data. On the other hand, we think that dissemination score and age score are sufficient.

\section{Study Limitations}

There are some limitations in this study; firstly, when laboratory parameters were investigated, we examined admission values. Although some studies have examined final laboratory parameters, we chose this method due to insufficient data in our study. Secondly, in many studies, correlation of mortality with affected body area and laboratory parameters, such as magnesium and alkaline phosphatase have been investigated. Due to the retrospective nature of our study, these variables were missing. Thirdly, we could not apply an anaerobic culture to our wound/tissue samples due to technical difficulties and this might have caused a relatively low positive wound culture rate in our study.

\section{Conclusion}

In spite of advances in treatment modalities, FG continues to be a life-threatening disease. To predict the patients' prognosis in $\mathrm{FG}$, the FGSI and UFGSI are successful parameters especially in predicting mortality. In the light of these parameters, we consider that more aggressive treatment in the first line may be a smart approach for some patients.

\section{Ethics}

Ethics Committee Approval: Ethics committee approval was not obtained due to the retrospective design of the study.

Informed Consent: Written informed consent was obtained from each patient.

Peer-review: Externally peer-reviewed.

\section{Authorship Contributions}

Concept: S.Y., E.I., Design: S.Y., E.I., H.T., M.S., Data Collection or Processing: A.Y., M.Y., N.A., Analysis or Interpretation: S.Y., E.I., H.T., M.S., Literature Search: S.Y., E.I., H.T., M.S., Writing: M.Y., E.I.

Conflict of Interest: No conflict of interest was reported by the authors.

Financial Support: The authors declared that they did not receive any financial support for this study.

\section{References}

1. Vick R, Carson CC. Fournier's disease. Urol Clin North America 1999;26:841849.

2. Pawlowski W, Wronski M, Krasnodebski IW. Fournier's gangrene. Pol Merkur Lekarski 2004;17:85-87.

3. Yeniyol CO, Suelozogen T, Arslan M, Ayder RA. Fournier's gangrene: experience with 25 patients and the use of Fournier's gangrene severity index score. Urology 2004;64:218-222.

4. Shanker M, Singhal V, Singh JP, Bansal A, Saxena S. Squamous cel carcinoma developing in the scar of Fournier's gangrene: case report. BMC Cancer 2004;4:16

5. Laor E, Palmer LS, Tolia BM . Outcome prediction in patients with Fournier's gangrene. J Urol 1995;154:89-92.

6. Yilmazlar T, Ozturk E, Ozguc H. Fournier's gangrene: an analysis of 80 patients and a novel scoring system. Tech Coloproctol 2010;14:217-223.

7. Fournier JA. Gangrene foudroyante de la verge. Semin Med 1883;3:345.

8. Sorensen MD, Krieger JN, Rivara FP, Broghammer JA, Klein MB, Mack CD, Wessels H. Fournier's Gangrene: population based epidemiology and outcomes. J Urol 2009;182:2742-2747.

9. Eke N. Fournier's gangrene: a review of 1726 cases. Br J Surg 2000;87:718 728

10. Benjelloun el B, Souiki T, Yakla N, Ousadden A, Mazaz K, Louchi A, Kanjaa N, Khalid A T. Fournier's gangrene: our experience with 50 patients and analysis of factors affecting mortality. World J Emerg Surg 2013;8:13.

11. Corcoran AT, Smaldone MC, Gibbons EP, Walsh TJ, Davies BJ. Validation of the Fournier's gangrene severity index in a large contemporary series. J Urol 2008;180:944-948. 
12. Yılmazlar T, Işık Ö, Öztürk E, Özer A, Gülcü B, Ercan I. Fournier's gangrene: review of 120 patients and predictors of mortality. Ulus Travma Acil Cerrahi Derg 2014;20:333-337.

13. Tuncel $A$, Keten $T$, Aslan $Y$, Kayali $M$, Erkan A, Koseoglu $E_{1}$ Atan A. Comparison of different scoring systems for outcome prediction in patients with Fournier's gangrene:experience with 50 patients. Scand J Urol 2014;48:393399.

14. Roghmann F, von Bodman C, Löppenberg B, Hinkel A, Palisaar J, Noldus $\mathrm{J}$. Is there a need for the Fournier's gangrene severity index? Comparison of scoring systems for outcome prediction in patients with Fournier's gangrene. BJU Int 2012;110:1359-1365.

15. Khandelwal $R$, Tandon $M$, Saradna, $A$, Gupta, $D$, Bahl B. Fournier's gangrene severity index as a predictor of outcome in patients with Fournier's gangrene: a prospective clinical study at a tertiary care center. Journal of Young Medical Researchers 2013;1:1-5.

16. Soh CR, Pietrobon R, Freiberger JJ, Chew ST, Rajgor D, Gandhi M, Shah J. Hyperbaric oxygen therapy in necrotising soft tissue infections: a study of patients in the United States Nationwide Inpatient Sample. Intensive Care Med 2012;38:1143-1151.

17. Capelli-Schellpfeffer M1, Gerber GS. The use of hyperbaric oxygen in urology. J Urol 1999;162:647-654.
18. Czymek R, Schmidt A, Eckmann C, Bouchard R, Wulff B, Laubert T, Limmer $\mathrm{S}$, Bruch H P, Kujath P. Fournier's gangrene: vacuum-assisted closure versus conventional dressings. Am J Surg 2009;197:168-176.

19. Ozturk $E_{1}$ Ozguc $H$, Yilmazlar T. The use of vacuum assisted closure therapy in the management of Fournier's gangrene. Am J Surg 2009;197(5):660665; discussion 665 .

20. Estrada O, Martinez I, Del Bas M, Salvans S, Hidalgo LA. Rectal diversion without colostomy in Fournier's gangrene. Tech Coloproctol 2009;13:157159.

21. Lin TY, Ou CH, Tzai TS, Tong YC, Chang CC, Cheng HL, Yang W H, Lin Y M. Validation and simplification of Fournier's gangrene severity index. Int $\mathrm{J}$ Urol 2014;21:696-701.

22. Erol B, Tuncel A, Hanci V, Tokgoz H, Yildiz A, Akduman B, Kargi E, Mungan A. Fournier's gangrene: overview of prognostic factors and definition of new prognostic parameter. Urology 2010;75:1193-1198.

23. Erol B, Tuncel A, Tok A, Hanci V, Sari U, Sendogan F, Budak S, Aydemir $\mathrm{H}$, Amasyali A S, Yildirim A, Caskurlu T. Low magnesium levels an important new prognostic parameter can be overlooked in patients with Fournier'sgangrene: a multicentric study.Int Urol Nephrol 2015;47:19391945. 